Article

\title{
Impacts of COVID-19 on the Green Industry
}

\author{
Pulkit Marwah ${ }^{1} \mathbb{D}$, Yu Yvette Zhang ${ }^{1, *}$ and Mengmeng Gu ${ }^{2} \mathbb{D}$ \\ 1 Department of Agricultural Economics, Texas A\&M University, College Station, TX 77843, USA; \\ pulkit.marwah91@tamu.edu \\ 2 Department of Horticultural Sciences, Texas A\&M AgriLife Extension Service, \\ College Station, TX 77843, USA; mgu@tamu.edu \\ * Correspondence: Yzhang@tamu.edu
}

check for

updates

Citation: Marwah, P.; Zhang, Y.Y.; $\mathrm{Gu}, \mathrm{M}$. Impacts of COVID-19 on the Green Industry. Horticulturae 2021, 7, 329. https://doi.org/10.3390/ horticulturae7100329

Academic Editor: Christian Fischer

Received: 27 July 2021

Accepted: 16 September 2021

Published: 23 September 2021

Publisher's Note: MDPI stays neutral with regard to jurisdictional claims in published maps and institutional affiliations.

Copyright: (c) 2021 by the authors. Licensee MDPI, Basel, Switzerland. This article is an open access article distributed under the terms and conditions of the Creative Commons Attribution (CC BY) license (https:// creativecommons.org/licenses/by/ $4.0 /)$.

\begin{abstract}
The COVID-19 pandemic has forced many horticultural businesses to alter the way they operate. This includes, but may not be limited to, changing hours of operation, working with limited staff, and restricting customer access indoors. This could result in several challenges for businesses. In this study, we evaluate the impacts of COVID-19 on the green industry in the U.S. and identify the challenges for businesses. Based on our research findings, the major challenges faced by businesses were not having enough employees and inventory to keep up with consumer demand during COVID-19. We also evaluate the effect of the pandemic on the sales of different plants, gardening products/services, and the overall revenues of businesses. For different types of plants included in the survey, landscape herbaceous flowers, landscape shrubs, and landscape trees showed the most significant increase in sales. In addition, for different gardening products/services, container plants, small plants, and soil and compost showed the most significant increase in sales. A total of $64 \%$ of the businesses reported higher overall sales compared to the same season's previous year, while less than $24 \%$ of the businesses reported decreased sales. Moreover, over $46 \%$ of the businesses indicated that COVID-19 had positively affected their sales in 2020, while 31\% thought that it had negatively impacted their sales. These findings imply a greater demand potential for plants and gardening products/services from consumers, during this pandemic.
\end{abstract}

Keywords: COVID-19; SARS-CoV-2; green industry; horticulture; gardening; nursery; landscape; business survey

\section{Introduction}

The COVID-19 pandemic is a health tragedy on a global scale. It has changed the world in numerous ways - quality of life, political, environmental, and economic sustainable development [1]. Businesses worldwide, as well as the United States economy, have been impacted. It is estimated that the United States real GDP suffered a year-on-year contraction of almost $11 \%$ in 2020 [2]. The green industry is an important part of the United States economy. According to the 2019 USDA NASS Census of Horticultural Specialties, the value of all horticultural crops sold was over USD13.7 billion [3]. Therefore, understanding the effect of this pandemic on the industry, for plants and gardening products/services, is important.

In this study, we evaluate the influence of COVID-19 on the green industry. The pandemic has had an effect on the consumers, making it imperative for businesses to adapt to the new normal. As the pandemic forced people into isolation, they have been facing periods of stress [4]. Therefore, the potential benefits of being in contact with nature are gaining more importance [5]. In fact, extant literature suggests that leisure activities are being associated with tending to flowers and ornamental plants [4]. Moreover, gardening has been reported to be effective in alleviating the undesirable effects of isolation caused by the pandemic [6]. This might suggest a potentially higher demand for horticultural products. In addition, foreign countries' export of horticultural products saw a sharp 
decline in 2020 [7]. This might imply a lower supply of horticultural products in the U.S market.

The pandemic has also forced businesses to alter the way they operate. This includes, but may not be limited to, changing hours of operation, working with limited staff, and restricting customer access indoors. This could result in several challenges for businesses. We were able to shortlist the major challenges faced by businesses due to the pandemic.

We also evaluate the effect of the pandemic on the sales of different plants, gardening products/services, and the overall revenues of businesses. An important objective of this study is to investigate the extent of these impacts on different businesses based on their size (number of employees), business type (family or individual operation, incorporated), type of operation (retail, wholesale, etc.), and revenue.

\section{Materials and Methods}

\subsection{Producer Survey}

We used the data from a Texas Nursery \& Landscape Association (TNLA) survey. TNLA members are representative of the full spectrum of the green industry in Texas, and include growers, re-wholesalers, retail centers, and landscapers. TNLA sent out the survey to their members in September 2020, and 67 members responded to this survey regarding the impact that the pandemic has had on the different components of their businesses, such as availability of employees, market access, and inventory management. The participants were asked to rate each issue on a scale of 1 to $5(1=$ not challenging at all, 2 = slightly challenging, 3 = challenging but manageable, $4=$ definitely challenging, $5=$ very challenging). The relative importance index (RI) can be employed to compare the ranking of all the challenges faced by the businesses, based on their relative severity [8]. RI has been used in horticulture, engineering research, and project management (e.g., [9-14]). The following formula is used to calculate the RI [15]:

$$
\mathrm{RI}=\sum \frac{I}{H \times N}
$$

Here, $I$ is the "importance" assigned by the survey respondents. In this study it refers to the severity of the challenge, on a scale of one to five $(1=$ not challenging at all, 2 = slightly challenging, 3 = challenging but manageable, 4 = definitely challenging, 5 = very challenging), $H$ is the value for highest severity, and $N$ is the total number of survey participants $[9,15]$.

The survey participants were also asked about the changes in their business operations that they had to incorporate in light of the pandemic, such as changing hours of operation, working with limited staff, and restricting customer access indoors. We also asked the participants to choose the main factor affecting their sales (increase in sales, decrease in sales, and no effect) in 2020, from the following-COVID-19, weather, and general economy prior to COVID-19. Additionally, the survey also collected data on the size (number of employees), type of operation (landscaper, grower, retail, supplier, arborist, rewholesaler), business type (partnership, individual or family, incorporated), and revenue for the businesses, in order to study the effect that the pandemic has had on different types of businesses. The plants included in the survey were: vegetables, fruits, florist-type plants, landscape herbaceous flowers, landscape shrubs, and landscape trees. In addition, the gardening products/services included in the survey were: landscaping, seeds, small plants, container plants, bareroot plants, soil and compost, fertilizer and chemicals, and gardening accessories.

\subsection{Econometric Model}

We investigated the impact of COVID-19 on sales of horticultural businesses controlling for important factors such as business size (no. of employees), revenue, operation type (grower, retailer, landscaper, etc.), business type (partnership, family or individual, incorporated), and changes in business operations (open with modified procedures or 
with no access for customers). We employed an ordered logit model for our analysis as described in Equation (2) [16,17]:

$\operatorname{logit}(\mathrm{Y})=\alpha_{0}+\alpha_{1}$ (operation $)+\alpha_{2}($ size $)+\alpha_{3}($ revenue $)+\alpha_{4}$ (operation type $)+\alpha_{5}$ (business type $)+\varepsilon$

The dependent variable $\mathrm{Y}$ in our analysis is the change in sales for the businesses. $\mathrm{Y}$ ranged from -2 to $2(-2=$ significantly decreased, $-1=$ moderately decreased, $0=$ no change, $1=$ moderately increased, $2=$ significantly increased).

$\alpha_{0}$ represents an intercept, while the effects of changes in operation (open with modifications/no customer access), business size (employees), revenue, operation type (grower, retailer, landscaper, etc.), and business type (partnership/individual/incorporated) are reflected by parameters $\alpha_{1}, \alpha_{2}, \alpha_{3}, \alpha_{4}$, and $\alpha_{5}$, respectively [16].

\section{Results}

\subsection{Producer Sales}

For all types of plants, as well as gardening products and services included in our study, with the exception of bare root plants, the percentage of businesses reporting higher sales outweighed the percentage of businesses reporting decreased sales (Figures 1 and 2). For different types of plants included in the survey, landscape herbaceous flowers, landscape shrubs, and landscape trees showed the most significant increase in sales. In addition, for different gardening products/services, container plants, small plants, and soil and compost showed the most significant increase in sales.

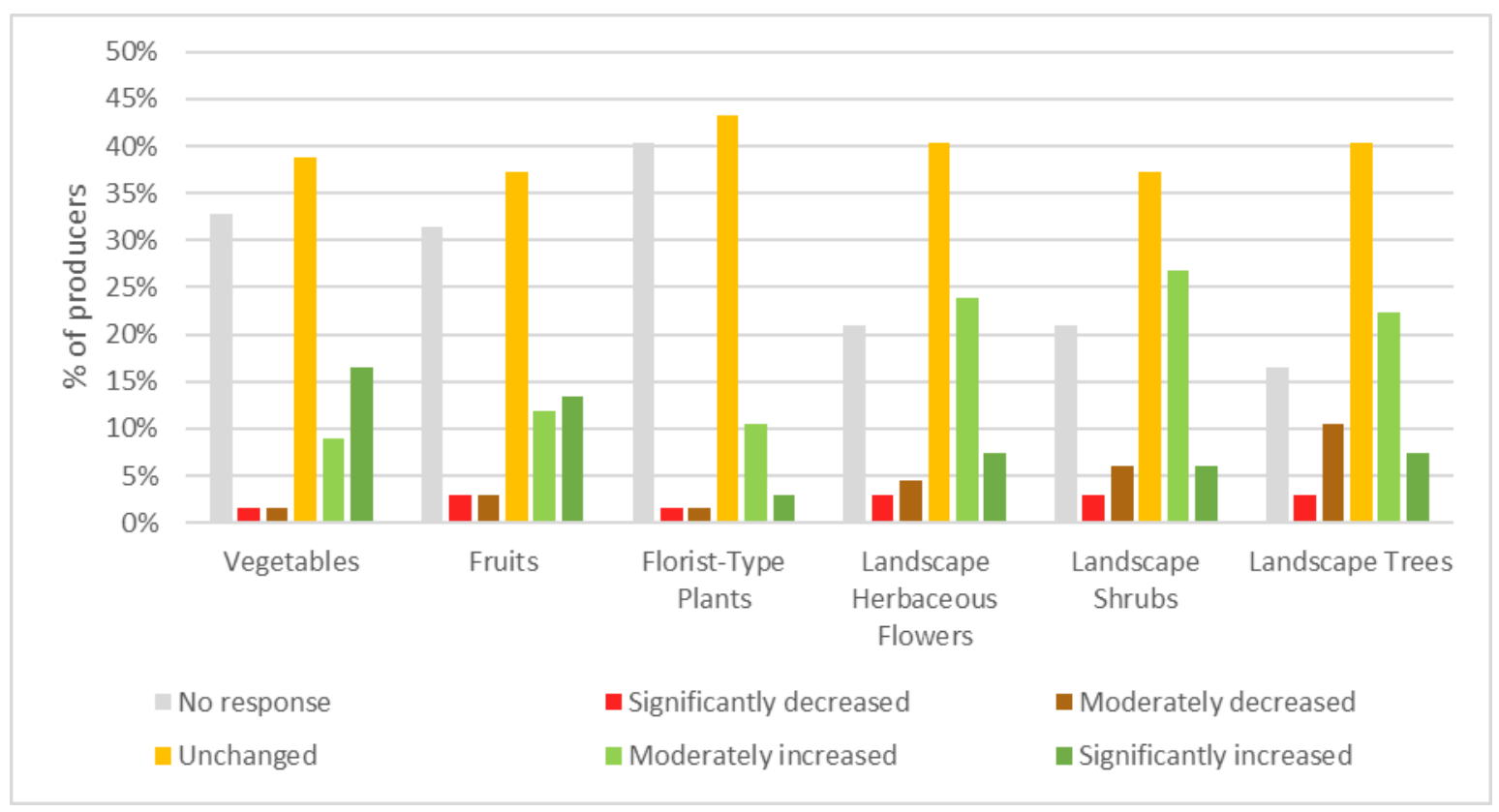

Figure 1. Percentage of producers who indicated change in purchases of plants during the pandemic, based on producer surveys. 


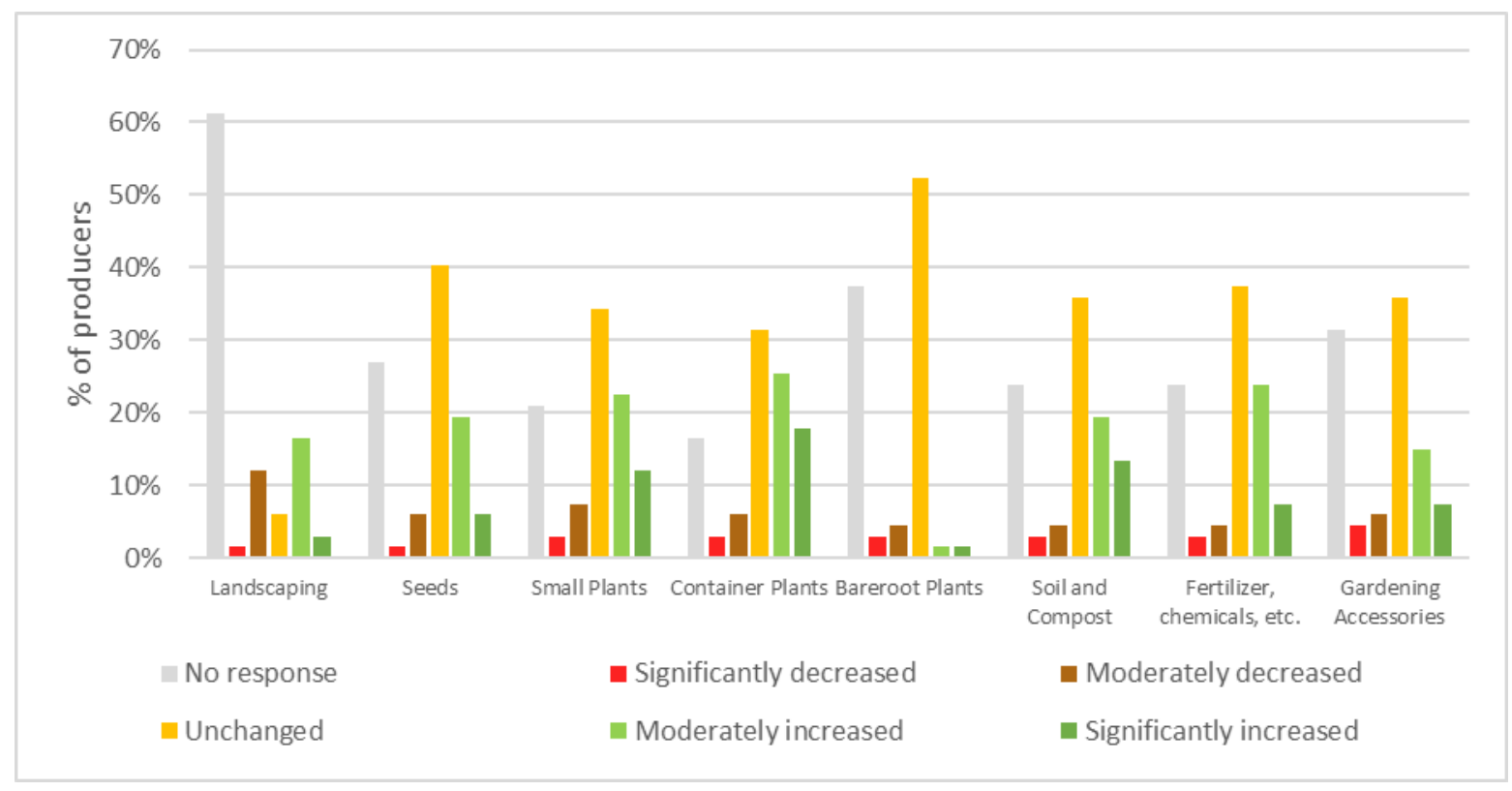

Figure 2. Percentage of producers who indicated change in purchasing of gardening products/services during the pandemic, based on producer surveys.

\subsection{Effects of Business Size and Total Revenue}

The summary statistics for the survey are described in Table 1. Different operation types included landscaper, grower, retail, supplier, arborist, and re-wholesaler. The main business types included incorporated under state law, partnerships, and family or individual operations. A total of $58.21 \%$ of businesses were open as before COVID- 19 , while others reported modified operations. In total, $64 \%$ of the businesses reported higher overall sales (compared to the same season's previous year), while less than $24 \%$ of the businesses reported decreased sales and less than $12 \%$ of them reported no change in sales. Moreover, over $46 \%$ of the businesses indicated that COVID-19 had positively affected their sales in 2020 , while $31 \%$ thought that it had negatively impacted their sales in 2020 and $23 \%$ of the businesses believed that COVID-19 had no impact on their sales.

Table 1. Characteristics of survey respondents.

\begin{tabular}{|c|c|}
\hline Category & Percentage \\
\hline \multicolumn{2}{|l|}{ Operation Type } \\
\hline Landscaper & $31.34 \%$ \\
\hline Grower & $29.85 \%$ \\
\hline Retail & $17.91 \%$ \\
\hline Supplier & $14.93 \%$ \\
\hline Arborist & $4.48 \%$ \\
\hline Re-wholesaler & $1.49 \%$ \\
\hline \multicolumn{2}{|l|}{ Change in Operation due to COVID-19 } \\
\hline Open, as before COVID-19 & $58.21 \%$ \\
\hline Open-with modified procedures (remote staff, limited staff, limited hours) & $34.33 \%$ \\
\hline $\begin{array}{l}\text { Open-no customer access (phone or online ordering, pick-up or } \\
\text { delivery only) }\end{array}$ & $5.97 \%$ \\
\hline Closed-management decision & $1.49 \%$ \\
\hline \multicolumn{2}{|l|}{ Change in Sales during COVID-19 } \\
\hline Significantly decreased & $14.93 \%$ \\
\hline Moderately decreased & $8.96 \%$ \\
\hline No change & $11.94 \%$ \\
\hline Moderately increased & $40.30 \%$ \\
\hline Significantly increased & $23.88 \%$ \\
\hline
\end{tabular}


Table 1. Cont.

\begin{tabular}{lc}
\hline \multicolumn{1}{c}{ Category } & Percentage \\
\hline Business Type & \\
Incorporated under state law & $70.15 \%$ \\
Partnership-include family partnerships & $17.91 \%$ \\
Family or individual operation-exclude partnerships and corporations & $10.45 \%$ \\
Other, such as estate or trust, prison farm, grazing association, American & $1.49 \%$ \\
Indian Reservation, etc. Please specify & \\
\hline Number of Employees & \\
Less than 10 & $23.88 \%$ \\
10 to 49 & $46.27 \%$ \\
50 to 99 & $10.45 \%$ \\
100 to 499 & $14.93 \%$ \\
More than 500 & $4.48 \%$ \\
\hline Total Revenue & \\
USD0 to USD9999 & $1.49 \%$ \\
USD100,000 to USD249,999 & $5.97 \%$ \\
USD250,000 to USD349,999 & $5.97 \%$ \\
USD350,000 to USD500,000 & $5.97 \%$ \\
USD500,000 to USD749,999 & $2.99 \%$ \\
USD750,000 to USD999,999 & $8.96 \%$ \\
USD1,000,000 to USD1,099,999 & $4.48 \%$ \\
USD1,100,000 to USD4,999,999 & $34.33 \%$ \\
USD5,000,000 to USD7,999,999 & $1.49 \%$ \\
Over USD8,000,000 & $28.36 \%$ \\
\hline
\end{tabular}

The estimates from our ordered logit model for change in businesses' sales are shown in Table 2. Based on the type of operation, the retail operations were associated with a 16 times higher probability of increased sales compared to the growers (base). The results were not statistically significant for other business types. In terms of changes in daily operations, the difference was not statistically significant as businesses shifted from "openas before COVID-19" to "open-with modifications" or "open-with no customer access". We also found that the effects of the number of employees and revenue on overall sales during the pandemic were not statistically significant.

Table 2. Ordered logit model estimates for change in overall sales due to modified operations, business size, business type, operation type, and revenue.

\begin{tabular}{lccc}
\hline \multicolumn{1}{c}{ Change in Sales } & Odds Ratio & SE & $p>|\mathbf{z}|$ \\
\hline $\begin{array}{l}\text { Change in operation } \\
\text { (Base = Open-as before COVID-19) }\end{array}$ & & & \\
Open-with modifications & 0.795 & 0.487 & 0.708 \\
Open-no customer access & 0.680 & 0.669 & 0.695 \\
\hline Operation Type & & & \\
(Base = Grower) & & & \\
Arborist & 0.292 & 0.366 & 0.326 \\
Landscaper & 0.393 & 0.287 & 0.201 \\
Retail & $16.515 * * *$ & 14.564 & 0.001 \\
Supplier & 1.685 & 1.361 & 0.518 \\
\hline Business Type & & & \\
(Base = Family or Individual operation) & & & \\
Incorporated under state law & 0.479 & 0.439 & 0.422 \\
Partnership—include family partnerships & 0.539 & 0.561 & 0.553 \\
\hline Size (per 10 employees) & 1.032 & 0.029 & 0.255 \\
\hline Revenue (in USD100,000) & 1.005 & 0.012 & 0.667 \\
\hline$* * * p<0.01$. & & & \\
\hline
\end{tabular}


The estimates from our ordered logit model for the change in sales of different plants and gardening products are shown in Table 3 . An important result from our analysis was a difference in the change of sales of different plants and gardening products based on the type of operation. Compared to the growers (base), retail operations were associated with a higher probability of increased sales for seeds, small plants, container plants, soil and compost, fertilizer and chemicals, gardening accessories, and florist-type plants. Supplier operations were associated with a higher probability of increased sales for small plants, container plants, vegetables, and fruits.

Table 3. Ordered logit model estimates for change in sales of plants and gardening products.

\begin{tabular}{|c|c|c|c|c|c|c|}
\hline Change in Sales & Odds Ratio & $p>|z|$ & Odds Ratio & $p>|z|$ & Odds Ratio & $p>|z|$ \\
\hline & \multicolumn{2}{|c|}{ Landscaping } & \multicolumn{2}{|c|}{ Seeds } & \multicolumn{2}{|c|}{ Small Plants } \\
\hline \multicolumn{7}{|l|}{$\begin{array}{c}\text { Change in operation } \\
(\text { Base }=\text { Open }- \text { as before COVID-19) }\end{array}$} \\
\hline Open-with modifications & 1.35 & 0.8 & 2.75 & 0.21 & 1.63 & 0.52 \\
\hline Open-no customer access & - & - & $0.00 * *$ & 0.01 & 0.2 & 0.25 \\
\hline \multicolumn{7}{|l|}{$\begin{array}{l}\text { Operation Type } \\
\text { (Base = Grower) }\end{array}$} \\
\hline Arborist & - & - & 0.22 & 0.35 & 0.18 & 0.19 \\
\hline Landscaper & 0.53 & 0.66 & 0.5 & 0.5 & $0.12^{* *}$ & 0.02 \\
\hline Retail & 3.63 & 0.42 & $46.02 * * *$ & 0 & $16.92 * * *$ & 0.01 \\
\hline Supplier & 3.97 & 0.43 & 0.99 & 1 & $0.14^{* *}$ & 0.04 \\
\hline \multirow{2}{*}{\multicolumn{7}{|c|}{$\begin{array}{c}\text { Business Type } \\
\text { (Base }=\text { Family or individual operation })\end{array}$}} \\
\hline & & & & & & \\
\hline Incorporated under state law & 1.37 & 0.82 & 0.44 & 0.56 & 0.6 & 0.64 \\
\hline Partnership_include family partnerships & 2.99 & 0.55 & 0.5 & 0.68 & 0.48 & 0.57 \\
\hline Size (per 10 employees) & 0.99 & 0.77 & 0.99 & 0.86 & 1.02 & 0.55 \\
\hline \multirow[t]{2}{*}{ Revenue (in USD100,000) } & 1 & 0.97 & 0.98 & 0.31 & 1 & 0.99 \\
\hline & \multicolumn{2}{|c|}{ Container Plants } & \multicolumn{2}{|c|}{ Soil and Compost } & \multicolumn{2}{|c|}{$\begin{array}{l}\text { Fertilizer and } \\
\text { Chemicals }\end{array}$} \\
\hline \multicolumn{7}{|l|}{$\begin{aligned} & \text { Change in operation } \\
(\text { Base }= & \text { Open }- \text { as before COVID-19) }\end{aligned}$} \\
\hline Open-with modifications & 1.64 & 0.51 & 2.38 & 0.24 & 1.7 & 0.47 \\
\hline Open-no customer access & 3.12 & 0.4 & $0.06 *$ & 0.06 & 0.12 & 0.15 \\
\hline \multicolumn{7}{|l|}{$\begin{array}{l}\text { Operation Type } \\
(\text { Base }=\text { Grower })\end{array}$} \\
\hline Arborist & 0.12 & 0.11 & 0.21 & 0.28 & 0.41 & 0.54 \\
\hline Landscaper & $0.09 * *$ & 0.01 & 0.51 & 0.47 & 0.48 & 0.43 \\
\hline Retail & $28.31 * * *$ & 0 & 11.44 ** & 0.01 & $8.68^{* *}$ & 0.02 \\
\hline Supplier & $0.07^{* * *}$ & 0.01 & 0.8 & 0.83 & 0.99 & 0.99 \\
\hline \multicolumn{7}{|l|}{$\begin{array}{c}\text { Business Type } \\
(\text { Base }=\text { Family or individual operation })\end{array}$} \\
\hline Incorporated under state law & 0.6 & 0.65 & 1.63 & 0.65 & 1.63 & 0.7 \\
\hline Partnership-include family partnerships & 0.5 & 0.6 & 1.16 & 0.91 & 1.16 & 0.92 \\
\hline Size (per 10 employees) & 1.03 & 0.35 & 0.98 & 0.6 & 1.03 & 0.42 \\
\hline \multirow[t]{2}{*}{ Revenue (in USD100,000) } & 1 & 0.92 & 0.99 & 0.42 & 0.99 & 0.59 \\
\hline & \multicolumn{2}{|c|}{$\begin{array}{l}\text { Gardening } \\
\text { Accessories }\end{array}$} & \multicolumn{2}{|c|}{ Vegetables } & \multicolumn{2}{|c|}{ Fruits } \\
\hline \multicolumn{7}{|l|}{$\begin{array}{c}\text { Change in operation } \\
(\text { Base }=\text { Open-as before COVID-19) }\end{array}$} \\
\hline Open-with modifications & 2.07 & 0.34 & 6.59 & 0.1 & 1.3 & 0.75 \\
\hline $\begin{array}{l}\text { Open-no customer access } \\
\text { Operation Type } \\
(\text { Base }=\text { Grower })\end{array}$ & $1.50 \times 10^{7}$ & 0.99 & 0 & 0.2 & 0.99 & 1 \\
\hline Arborist & 0.7 & 0.83 & 0.02 & 0.14 & $0.04 *$ & 0.08 \\
\hline
\end{tabular}


Table 3. Cont.

\begin{tabular}{|c|c|c|c|c|c|c|}
\hline Change in Sales & Odds Ratio & $p>|z|$ & Odds Ratio & $p>|z|$ & Odds Ratio & $p>|\mathbf{z}|$ \\
\hline Landscaper & $0.13 *$ & 0.08 & $0.03 * *$ & 0.02 & $0.01 * * *$ & 0 \\
\hline Retail & $21.18^{* *}$ & 0.01 & $7.67 *$ & 0.06 & 3.78 & 0.14 \\
\hline Supplier & 2.63 & 0.42 & $0.04 * *$ & 0.03 & $0.03^{* *}$ & 0.02 \\
\hline \multicolumn{7}{|l|}{ Business Type } \\
\hline \multicolumn{7}{|l|}{ (Base $=$ Family or individual operation) } \\
\hline Incorporated under state law & 0.18 & 0.22 & 0.39 & 0.51 & 0.24 & 0.25 \\
\hline Partnership-include family partnerships & 0.14 & 0.24 & 0.03 * & 0.06 & 0.33 & 0.47 \\
\hline Size (per 10 employees) & 1 & 0.97 & 0.94 & 0.16 & 1.03 & 0.49 \\
\hline \multirow[t]{2}{*}{ Revenue (in USD100,000) } & 1.02 & 0.47 & 1.02 & 0.29 & 1 & 0.85 \\
\hline & \multicolumn{2}{|c|}{ Florist-Type Plants } & \multicolumn{2}{|c|}{$\begin{array}{l}\text { Landscape } \\
\text { Herbaceous Plants }\end{array}$} & \multicolumn{2}{|c|}{ Landscape Shrubs } \\
\hline \multicolumn{7}{|l|}{$\begin{array}{c}\text { Change in operation } \\
(\text { Base }=\text { Open-as before COVID-19) }\end{array}$} \\
\hline Open-with modifications & $12.08 *$ & 0.07 & 2.43 & 0.24 & 1.13 & 0.86 \\
\hline \multicolumn{7}{|l|}{ Operation Type } \\
\hline Arborist & 0.41 & 0.76 & 0.12 & 0.16 & 0.24 & 0.32 \\
\hline Landscaper & 0.08 & 0.2 & $0.06^{* * *}$ & 0 & 0.25 & 0.14 \\
\hline Retail & $28.84^{* *}$ & 0.04 & 2.79 & 0.23 & 4.15 & 0.14 \\
\hline Supplier & 0.09 & 0.33 & $0.11^{* *}$ & 0.03 & $0.13^{* *}$ & 0.05 \\
\hline \multicolumn{7}{|l|}{ Business Type } \\
\hline Incorporated under state law & $6.00 \times 10^{11}$ & 1 & 2.28 & 0.51 & 0.74 & 0.81 \\
\hline Partnership-include family partnerships & $2.00 \times 10^{10}$ & 1 & 4.46 & 0.31 & 0.68 & 0.78 \\
\hline Size (per 10 employees) & 0.83 & 0.14 & 1 & 0.91 & 1.05 & 0.14 \\
\hline Revenue (in USD100,000) & 1.05 & 0.21 & 1 & 0.84 & 1 & 0.92 \\
\hline & \multicolumn{6}{|c|}{ Landscape Trees } \\
\hline \multicolumn{7}{|l|}{$\begin{aligned} & \text { Change in operation } \\
(\text { Base }= & \text { Open-as before COVID-19) }\end{aligned}$} \\
\hline Open-with modifications & & 1.2 & & & 0.79 & \\
\hline Open-no customer access & & 1.86 & & & 0.58 & \\
\hline \multicolumn{7}{|l|}{$\begin{array}{l}\text { Operation Type } \\
\text { (Base= Grower) }\end{array}$} \\
\hline Arborist & & 0.34 & & & 0.39 & \\
\hline Landscaper & & 0.56 & & & 0.47 & \\
\hline Retail & & 1.46 & & & 0.65 & \\
\hline Supplier & & 0.31 & & & 0.18 & \\
\hline \multirow{2}{*}{\multicolumn{7}{|c|}{$\begin{array}{c}\text { Business Type } \\
\text { (Base }=\text { Family or individual operation) }\end{array}$}} \\
\hline & & & & & & \\
\hline Incorporated under state law & & 0.43 & & & 0.43 & \\
\hline Partnership-include family partnerships & & 0.6 & & & 0.68 & \\
\hline Size (per 10 employees) & & $1.05 *$ & & & 0.08 & \\
\hline Revenue (in USD100,000) & & 0.99 & & & 0.34 & \\
\hline
\end{tabular}

${ }^{* * *} p<0.01, * * p<0.05, * p<0.10$.

\subsection{Challenges Faced by Businesses Due to COVID-19}

Table 4 shows the weighted average rating on a scale of one to five $(1=$ not challenging at all, 2 = slightly challenging, 3 = challenging but manageable, $4=$ definitely challenging, $5=$ very challenging), as well as the Relative Importance Index (RI), for several issues faced by businesses due to the pandemic. Our findings indicated that the major challenges faced by the businesses were not having enough employees to keep up with the demand during COVID-19, not having enough inventory to meet the customer demand, and social distancing for employees. 
Table 4. Severity of challenges faced by businesses due to the pandemic on a scale of 1 to 5 ( $1=$ not challenging at all, 2 = slightly challenging, 3 = challenging but manageable, $4=$ definitely challenging, 5 = very challenging).

\begin{tabular}{ccc}
\hline Challenge & Rating & Relative Importance Index \\
\hline Not enough employees to keep up with demand & 2.86 & 0.571 \\
Not enough inventory to meet customer demand & 2.81 & 0.563 \\
Social distancing for employees & 2.54 & 0.507 \\
Social distancing for customers & 2.48 & 0.495 \\
Compliance with government COVID-19 & 2.47 & 0.494 \\
mandates & 2.45 & 0.490 \\
Covering work hours with available employee & 2.38 & 0.477 \\
Increase in operation costs due to COVID-19 & 2.29 & 0.458 \\
Access to government relief programs & 2.26 & 0.452 \\
Market access & 2.23 & 0.445 \\
Training workers & 1.93 & 0.386 \\
Delivering to other state & 1.90 & 0.379 \\
Keeping staff employed & 1.87 & 0.375 \\
Taxes & 1.84 & 0.369 \\
Cash flow obligations & 1.81 & 0.363 \\
Billing and collections & &
\end{tabular}

\section{Discussion}

Our research identified the main challenges faced by businesses during the pandemic, which could help businesses to adapt and strategize according to the changing market demand and improve their business decisions. Awareness regarding the major challenges, and the impact of the pandemic on changes in sales of businesses in general, as well as different products, would provide insight to governmental agencies while planning aid, relief programs, and assistance. The results from our producer surveys indicated that the pandemic has had a huge impact on the green industry, and has resulted in changes in sales of different plants and gardening products. This may have implications for businesses to prepare and optimize their inventory. Additionally, there was a sharp decline in foreign countries' export of horticultural products in 2020 [7]. Our results highlighted the challenge of meeting customer demand may also shed light on the impact on producers globally. It is important to note here that a limitation of this research was the small sample size. Future research may include a survey on a larger scale encompassing other U.S. states.

\section{Conclusions}

In general, businesses reported higher overall sales for all plants and gardening supplies during COVID-19, with the exception of bare root plants. An amount of $64 \%$ of the businesses indicated higher overall sales compared to the same season's previous year, while less than $24 \%$ of the businesses reported decreased sales. Moreover, over $46 \%$ of the businesses indicated that COVID-19 had positively affected their sales in 2020, while $31 \%$ thought that it had negatively impacted their sales. These are interesting findings, which imply a greater demand potential for plants and gardening products/services from consumers, in light of this pandemic. It is very important for businesses to match this potential demand in order to move towards economic recovery in the aftermath of the pandemic.

The major challenges that all businesses faced were the lack of enough employees to cover hours of operation, not enough inventory to keep up with the consumer demand, and social distancing for employees. Based on the type of operation, the retail-type businesses were associated with a 16 times higher probability of increased sales, compared to the growers (base). The results were not statistically significant for other business types. In terms of change in daily operations, the difference was not statistically significant as businesses shifted from "open-as before COVID-19" to "open—with modifications" or "open-with no customer access". We also found that the effects of the number of employ- 
ees and revenue on overall sales during the pandemic were not statistically significant. This suggests that, in general, the pandemic affected diverse businesses in a similar manner. For different plants and gardening products, we were able to analyze the effect on change in sales due to modified operations, type of operations, business type, size, and revenue. We found that retailers and suppliers were associated with a higher probability of increased sales for several plants and products. Results of this study provide important information for supply chain management, general operations, and marketing practices for businesses in the green industry, and can be useful to guide the businesses and the green industry to drive towards the economic recovery from COVID-19.

Author Contributions: Conceptualization, Y.Y.Z. and M.G.; methodology, Y.Y.Z. and P.M.; software, Y.Y.Z. and P.M.; validation, Y.Y.Z. and P.M.; formal analysis, Y.Y.Z. and P.M.; investigation, Y.Y.Z. and P.M.; resources, Y.Y.Z. and M.G.; data curation, Y.Y.Z. and P.M.; writing—original draft preparation, P.M.; writing-review and editing, Y.Y.Z., M.G. and P.M.; visualization, P.M.; supervision, Y.Y.Z. and M.G.; project administration, Y.Y.Z. and M.G.; funding acquisition, Y.Y.Z. and M.G. All authors have read and agreed to the published version of the manuscript.

Funding: This work was partially supported by the AmericanHort Horticultural Research Institute, Center for Applied Nursery Research, and the Specialty Crop Research Initiative project 'Systematic Strategies to Manage Crapemyrtle Bark Scale, An Emerging Exotic Pest' (grant no. 2017-5118126831/project accession no. 1013059) from the U.S. Department of Agriculture (USDA) National Institute of Food and Agriculture. Any opinions, findings, conclusions, or recommendations expressed in this publication are those of the author(s) and do not necessarily reflect the view of the USDA.

Institutional Review Board Statement: Not applicable.

Informed Consent Statement: Not applicable.

Data Availability Statement: Data sharing not applicable.

Acknowledgments: We thank the TNLA staff who conducted this survey, as well as TNLA members who participated in the survey. We would also like to acknowledge crapemyrtle bark scale research and extension team members (stopcmbs.com, accessed 2 September 2021) for their inputs and help.

Conflicts of Interest: The authors declare no conflict of interest.

\section{References}

1. Keshky, E.; El Sayed, M.; Basyouni, S.S.; Al Sabban, A.M. Getting through COVID-19: The Pandemic's Impact on the Psychology of Sustainability, Quality of Life, and the Global Economy-A Systematic Review. Front. Psychol. 2020, 11, 3188. [CrossRef] [PubMed]

2. Baker, S.; Bloom, N.; Davis, S.; Terry, S. COVID-Induced Economic Uncertainty; National Bureau of Economic Research: Cambridge, MA, USA, 2020. [CrossRef]

3. U.S. Department of Agriculture. NASS Census of Horticultural Specialties; USDA: Washington, DC, USA, 2019.

4. Bulgari, R.; Petrini, A.; Cocetta, G.; Nicoletto, C.; Ertani, A.; Sambo, P.; Ferrante, A.; Nicola, S. The Impact of COVID-19 on Horticulture: Critical Issues and Opportunities Derived from an Unexpected Occurrence. Horticulturae 2021, 7, 124. [CrossRef]

5. Sofo, A.; Sofo, A. Converting home spaces into food gardens at the time of COVID-19 quarantine: All the benefits of plants in this difficult and unprecedented period. Hum. Ecol. 2020, 48, 131-139. [CrossRef] [PubMed]

6. Lades, L.K.; Laffan, K.; Daly, M.; Delaney, L. Daily emotional well-being during the COVID-19 pandemic. Br. J. Health Psychol. 2020, 25, 902-911. [CrossRef] [PubMed]

7. Lin, B.X.; Zhang, Y.Y. Impact of the COVID-19 pandemic on agricultural exports. J. Integr. Agric. 2020, 19, 2937-2945. [CrossRef]

8. Tonidandel, S.; LeBreton, J.M. Relative importance analysis: A useful supplement to regression analysis. J. Bus. Psychol. 2011, 26, 1-9. [CrossRef]

9. Odeh, A.M.; Battaineh, H.T. Causes of construction delay: Traditional contracts. Int. J. Proj. Manag. 2002, 20, 67-73. [CrossRef]

10. Gündüz, M.; Nielsen, Y.; Özdemir, M. Quantification of delay factors using the relative importance index method for construction projects in Turkey. J. Manag. Eng. 2013, 29, 133-139. [CrossRef]

11. Torghabeh, Z.J.; Hosseinian, S.S.; Ressang, A. Relative Importance of Hazards at Construction Sites. Appl. Mech. Mater. 2013, 330, 867-871. [CrossRef]

12. Chan, D.W.; Kumaraswamy, M.M. A comparative study of causes of time overruns in Hong Kong construction projects. Int. J. Proj. Manag. 1997, 15, 55-63. [CrossRef] 
13. Kometa, S.T.; Olomolaiye, P.O.; Harris, F.C. Attributes of UK construction clients influencing project consultants' performance. Constr. Manag. Econ. 1994, 12, 433-443. [CrossRef]

14. Marwah, P.; Zhang, Y.Y.; Gu, M. Investigating Producers' Preferences for Crapemyrtle and Their Perceptions Regarding Crapemyrtle Bark Scale. Horticulturae 2021, 7, 146. [CrossRef]

15. Rooshdi, R.R.R.M.; Majid, M.Z.A.; Sahamir, S.R.; Ismail, N.A.A. Relative importance index of sustainable design and construction activities criteria for green highway. Chem. Eng. Trans. 2018, 63, 151-156. [CrossRef]

16. Nawrotzki, R.J.; Bakhtsiyarava, M. International Climate Migration: Evidence for the Climate Inhibitor Mechanism and the Agricultural Pathway. Popul. Space Place 2017, 23, e2033. [CrossRef] [PubMed]

17. Williams, R. Understanding and Interpreting Generalized Ordered Logit Models. J. Math. Sociol. 2016, 40, 7-20. [CrossRef] 